10.53116/pgaflr.2018.1.2

\title{
The Civil Service Law System in Poland - Selected Issues
}

\author{
Wojciech Drobny* \\ * Wojciech Drobny, PhD, Vice-Director General of the Institute of Law Studies, Polish Academy of \\ Sciences, specializes in Polish administrative law - civil service law. (e-mail: w.drobny@inp.pan.pl)
}

\begin{abstract}
The article refers to the topic of civil service law in Poland. It describes the organization of civil service system in comparison to other international solutions and it gives the historical background of how it has been evolving so far. Particularly it refers to the elements of its regime, the position and duties of the Polish Head of the Civil Service and rights and duties of the civil service corpus' members. The author claims that the changes taking place in the area of this part of law are due to the domination of private law (labor law) over public law (administrative law). This tendency currently prevails in the western legislation.
\end{abstract}

Keywords: civil service; administrative law; public governance; public administration

\section{Introduction}

The topic of the Polish civil service is still very much a current issue. A discussion on this topic is being held in Poland now by both administration, labor and constitutional law representatives. Therefore, the statements published in recent articles refer to the constitutional basis of the Polish civil service, to the labor rights and duties of the civil service members and not really to the public-private character of this law institution. Therefore, it makes sense to assess the changes in the law of office which regulates the legal status of government administration employees from the point of view of administration law rules. Researching such an area of studies and looking at it from historical perspective will let assess the state of the Polish civil service and formulate conclusions as to its changes.

The current act on the civil service of 21 November $2008^{1}$ in the last several years was the fourth act which has regulated in a totally new way the legal situation of the Polish government administration staff. Therefore, my first conclusion is that the legislator in the post-transformation period (after the system changes in 1989) was making the changes in an unplanned and inconsistent way. The big number of these changes violated the rules of good legislation, the quality of law, its continuity and security and what it leads to - the operational calm of public administration work. The changes made in the following acts of $1996,{ }^{2} 1998,{ }^{3} 2006^{4}$ and 2008 and at the same time parallel and alternative laws that were kept in force - act of 16 September 1982 on state posts officials ${ }^{5}$ - did not aim at building one coherent official corps, which, in my opinion, is a condition of a proper implementation of public duties. 
However, the law currently in force has been a long awaited legal act, necessary in the first place to eliminate the legal solutions of its predecessor i.e. the act on civil service from 2006 (and strictly connected with its act of 24 August 2006 on the state human resources and senior state positions). ${ }^{6}$ Some of the above-mentioned acts have been generally assessed not only as unacceptable but also incompatible with the Polish Constitution. To illustrate this well, let me mention the concept of liquidation of the government administration central organ, responsible for the civil service: Chief of the Civil Service, which, despite being criticized already on the stage of the legislative work, was introduced to the state law order in 2006. An experiment (described in Article 8 of this act) according to which the Prime Minister was in charge of the civil service (while the PM Chancellery Chief was to carry out tasks on behalf of the PM), has not defended itself against the accusation of the degradation of the current output in the area of the civil service (in the context of other proposed changes in the civil service organization, particularly creating the state human resources).

The current act on the civil service has liquidated the state human resources, high positions have been placed again within the civil service as well as the Civil Service Chief as the central organ of the government administration (his own post has not been restored but assigned to the PM Chancellery). Despite some concerns that will be discussed further on, this act is therefore a big improvement which can be called a partial restitution of the correct status of the Polish civil service. ${ }^{7}$

\section{General Assumptions of the Civil Service Law of 21 November 2008}

The current civil service law came in force on 24 March 2009 and complemented the law context of the Polish civil service corps through specifying the constitutional ${ }^{8}$ and systemic assumptions as well as describing the elements of the service regarding the civil service corps members in several decrees published by the PM and Civil Service Chief. The law has been amended several times and the amendments referred to the rules of the senior positions placement as well as the Board of Public Service, its duties and tasks. ${ }^{9}$ None of its articles has been so far controlled by the Polish Constitutional Tribunal ${ }^{10}$ but it has been a subject of Supreme Court cases a few times.

\section{Detailed Assumptions of the Civil Service Act of 21 November 2008}

Describing the chosen and, in my opinion, the most important elements of the legal status of the civil service corps members in view of the law from 2008, I need to state that the further assessment will be made based on the fact that the law of office is the natural part of administration law and the civil service is of a public-private character. In other words, the civil service is not only a tool or an instrument to carry out the political will nor is it a group of people employed to perform specific work but it is an important element of the 
philosophical concept of a "democratic country of law" whose constant attribute is a professional, objective and politically neutral staff corps which is protected by a catalog of guarantees.

\subsection{The Jurisdiction of Labor Courts with Regard to the Status of Civil Service Corps Members}

I agree with the opinion that the acceptance of the public-private concept of the employment relations at the same time meant that the employment relations belonged to the administrative law with all its process consequences as to its changes and solutions.

This assumption in a classic form was respected by the Polish legislator in the interwar period, ${ }^{11}$ when matters resulting from business relations were settled during the administrative procedure, ending in a decision appealing to the administrative court.

The exclusion of the principle of presumption of administrative court jurisdiction for common courts occurred at the moment of codification of labor law. ${ }^{12}$ From that moment, the possible submission of selected cassation cases to administrative courts required a separate legal basis or an appropriate, explicit reservation in the act. Despite the common classification of the legal status of members of the civil service corps as "public officials" (e.g. the verdict of the Provincial Administrative Court in Poznan of 13 March 2013 ${ }^{13}$ ) in the currently binding pragmatics, even a few examples of guaranteeing administrative lawchanging modes of action - despite the classic models of administrative and courtadministrative proceedings - were granted to the labor courts.

An excellent example of this is the civil service's right to appeal to the Prime Minister against the decision of the central government administration body competent in civil matters - the Head of the Civil Service in the matter of transferring him to another office (Article 67). The appeal procedure in this respect is governed by the provisions of the Code of Administrative Procedure ${ }^{14}$ but the decision of the Prime Minister may be appealed not to the administrative court, but to the labor court - in accordance with the general rule set out in Art. 9 pragmatics, according to which 'disputes over a claim regarding an employment relationship in the civil service are considered by labor courts. This was confirmed by the Voivodship Administrative Court in Warsaw in the judgment of 8 May $2012,{ }^{15}$ by unambiguously stating that in case of filling the vacant position by transfer, the legislator did not foresee control measures in the administrative course of the instance. Therefore, in such a situation, the complaint is inadmissible and subject to rejection.

A similar example of the questionable transfer of cases to the examination of labor courts is the system of protection of the civil service corps member in the assessment procedure. In the light of Art. 83 pragmatics from the periodic assessment of the corps member is used to oppose the director general of the office. If the objection is not met within the statutory deadline, or if the objection is not taken into account - which follows the law in the form of a "decision" - the corps member has the right to appeal again not to the administrative court, but to the labor court. This is indicated by the verdict of the Appeal Court in Rzeszów of 24 June 2014, ${ }^{16}$ in which "the right of the labor court to perform periodic review control in all its aspects was clearly confirmed. At the same time, 
it must determine whether the mode of the periodic assessment as well as its formal nature resulting from the act were taken into account strictly". This view was also shared by the Supreme Court in its judgment of 30 October 2013, ${ }^{17}$ stating that "the civil servant's objection from the periodic assessment is examined by the district court - the labor court".

It is worth noting that in the above context - in systemic terms - there is a glaring inconsistency of the Polish legislator in the elimination of public law elements in the employment relations of public officials. To prove this, it is enough to refer to the legal status of appointed controllers of the Supreme Audit Office ${ }^{18}$ or prison officers ${ }^{19}$ whose certain employee matters were explicitly excluded from the general jurisdiction court for administrative judiciary. Primarily I am referring to the possibility of challenging the decision to transfer to another organizational unit, terminating the employment relationship with notice and without notice and to appeal against the decision on the negative qualification.

\subsection{The Issue of Recruitment to the Civil Service Corps}

Recommendation of the Committee of Ministers of the Council of Europe ${ }^{20}$ on the status of public employees in Europe clearly indicates that the constructive element of proper recruitment to the public service is effective administrative supervision over this procedure and its judicial and administrative control. The importance of this issue was emphasized by the Polish Constitutional Tribunal, pointing out that the essence of a properly constructed recruitment process for the public service is the feature of competitiveness that characterizes it. It is why the proceedings need to be protected in court-administrative proceedings against arbitrary decisions, while at the same time constituting a procedural measure of constitutional review of the criteria of equal access to the same principle ${ }^{21}$ It follows - which is extremely important - that the omission of the competition fundamentally changes the legal position of people interested in public service, because it deprives them of proper protection against arbitrary decisions. The exclusion of the competition system means eliminating the path of judicial review of the correctness of applying the recruitment criteria to the civil service.

From the point of view of the assumptions made, the pragmatics in force did not create a fully correct concept of recruitment, did not guarantee the transparency of the proceedings, as well as clarity and understanding of the actions and decisions taken. Analyzing this law, it is not possible to read the substantive criteria, the fulfilment of which is a condition of access to public service. The candidate also has no knowledge as to the rules, methods, mode of operation and decision-making by the recruiters, as well as the general directors of offices responsible for conducting the proper conduct, who do not have any statutory guidelines as to the legislator's expectations in this respect. It will only fill in the gap when declaring open and competitive recruitment. What is more, the amendments introduced in 2015, changes in the scope of casting senior positions in the civil service, in particular the introduction of "appointment" as a legal basis for establishing employment relationships at the same time, enabling the appointment of people from 
outside the civil service corps, the required competition deepens the negative assessment of the solutions in this area.

On the other hand, the solutions of the Act on the Civil Service of 1996 may serve as an example of optimal consideration of the pragmatics of the above-mentioned conditions. It guaranteed the candidate who took part in the qualification procedure the right to request a written decision by the civil service body at that time. Although the 1996 Act did not specify expressis verbis that this decision was subject to appeal to the administrative court, nevertheless the doctrine rightly, consistently assumed that it had the character of an administrative decision. Such legal classification determined the possibility of being challenged by the Supreme Administrative Court with a request that the Qualifying Committee remove the violation of law.

\subsection{The Subjective Scope of the Civil Service Act}

In the light of the systemic assumptions of the Polish civil service, using the jurisprudence of the Constitutional Tribunal, one may put forward the thesis that in the constitution's view the civil service corps should cover all government administration offices. According to the wording of Art. 153 of the Constitution of the Republic of Poland, the sphere of action of the civil service corps are offices of the government administration, and the Prime Minister is the supervisor of this corps. The meaning of the term "government administration" can be determined on the basis of the definition of the term, the taxonomy of the Constitution and the interpretation presented by the Constitutional Tribunal.

Therefore, with his interpretation, it can be recalled that to recognize an office as a government administration office it is necessary to meet two conditions simultaneously, i.e. to perform tasks of public administration character and to place the state apparatus in this segment, headed by the Council of Ministers. In the justification to the judgment of 13 November $2003,{ }^{22}$ the Tribunal indicated that the wording of Art. 153 of the Constitution allows the adoption of a position that the entire clerical apparatus, performing tasks for public administration, in its part subject to the Council of Ministers, should be covered by the Act on Civil Service.

Meanwhile, the legislator in the content of the binding pragmatics is inconsistent in this respect. In addition to the statutory directory of offices covered by the civil service corps, there are unjustifiable entities that have their status in the structure of public administration in this part, headed by the Council of Ministers. A perfect example of this is the legal status of the Government Legislative Center, which was not legally covered by the civil service corps.

\subsection{System of Civil Service Organs}

I believe that granting - in the light of obligatory pragmatics - the Head of the Civil Service, the status of a central government administration body is optimal, but current regulations granting it insufficient catalog of competences may adversely affect the manner 
and effectiveness of his tasks. Incomplete scope of competences of the Head of the Civil Service, including the lack of significant supervisory or imperious powers, obviously limits the effectiveness of his actions and makes it impossible to enforce decisions. Therefore, I am of the opinion that the potential resulting from the status of a "central government administration body" 23 has not been fully used. The more so because the problem of its organizational separation still remains a problematic issue, because currently this body is supported by the Chancellery of the Prime Minister. The current legal situation in this respect is somewhat in contradiction with the theoretical assumptions of the "administrative body" model. The assumed lack of independence of this body in managing the auxiliary apparatus assigned to it to serve, contradicts the general concept of the status of such a body.

On the other hand, the analysis of the nature of the current powers of the Public Service Council reveals a certain inconsistency between its statutory declared status (i.e. an advisory and consultative body) and the rights it possesses. The direction of change adopted by the legislator perceived as positive in the provisions of the Act of 2008, in the light of which some strengthening of the position of this body by granting subsequent rights, should be considered positive. This testifies to the growing importance of the Council in the civil service system. Therefore, due to the actual tools in which it has been equipped in the current legal status, it may be necessary to consider a statutory change of the concept of the status of this body from consultative and advisory to approval and control.

The current provisions, in my opinion, do not guarantee the person holding the office of the general director of the office the appropriate status and sufficient tools to effectively implement the tasks assigned to the law. From the analysis of transformations of the legal status of this entity, in the light of successive office law pragmatists, there emerges a disturbing tendency to limit the role and importance of the director general of the office. His position in relation to the head of the office is weak, which may directly threaten the apolitical nature of the civil service corps. Some doubtful legal solutions can be found in the part of the Civil Service Act in which it enables the Director General to perform his duties - during his vacancy and in the situation of not finding a replacement - by a member of the civil service corps employed in that office. This may result in the practice of longterm failure of directors-general and long-term actual performance of these functions by people who do not meet the statutory conditions necessary to take up this position.

\subsection{Eligibility Procedure in the Civil Service}

Another key element having a fundamental impact on the correct status of the civil service is the qualification procedure in the civil service. Handover of the National School of Public Administration - in accordance with the Act of 1991 on the National School of Public Administration, ${ }^{24}$ the status of "legal person" - tasks in the organization of the recruitment procedure implied serious consequences for the legal position of the participant in this proceeding. As a result of this transfer (in accordance with the decision of the Supreme Administrative Court ${ }^{25}$ ) in the current legal state, "the qualification 
procedure" is in fact the so-called "Act of knowledge". In this dimension, in historical terms, the legal situation of a person applying for the status of civil servant has deteriorated. The legislator resigned from the solutions of earlier acts, in the light of which the central organ of public administration, that is the Head of the Civil Service, was responsible for conducting the qualification procedure, and then he transferred this responsibility to the "state legal person". This has far-reaching effects, mainly expressed in maintaining the legal status in which the participant in the recruitment procedure was deprived of adequate legal protection. The lack of instances in this proceeding and, consequently, also of judicial and administrative control from the point of view of administrative law principles - may be considered as controversial.

These are not only theoretical considerations, which is confirmed by the judicature, and which is illustrated by the judgment of the Provincial Administrative Court in Warsaw of 22 August $2012^{26}$ that ruled on the complaint of the person taking part in the qualification proceedings for inactivity of the National School of Public Administration, which according to the plaintiff 'consisted in the lack of appointment as a civil servant.' The court dismissed the complaint by rightly noting that administrative courts within their jurisdiction exercised control over the legality of actions or omissions of public administration bodies. Thus the National School of Public Administration was not the subject of the control - in other words, the Head of the Civil Service would be able to remain inactive if he was responsible for carrying out the qualifying procedure. The above legal classification of the recruitment procedure in another judgment was confirmed by the Supreme Administrative Court (referred to the aforementioned judgment of 6 February 2013), which stated that in the light of the current provisions, the recruitment procedure is not an administrative proceeding and cannot be subject to administrative court control, and consequently, the inadmissibility of the authority on this subject cannot be subject to control. What is extremely important, at the same time in the light of the judgments of administrative courts, the recruitment procedure is not a claim under the employment relationship - thus, Art. 9 of the Act on Civil Service in which there is a mention of court cognition in such matters. ${ }^{27}$

\section{Final Remarks}

I believe that the development in 2008 of pragmatics of the concept of organizing the civil service system, which restores the central government administration body competent in civil service matters and maintains a consultative and advisory body at the Prime Minister in civil service matters and finally introducing a statutory requirement to disseminate information about the recruitment to work in the civil service corps - although in discussions and subject to further improvement - are positive examples of achievements in the construction of this part of the public service.

This conclusion is important in the discussion on the possibility or legitimacy of adopting solutions applied in government administration in pragmatists regulating the legal status of employees of other "segments" of public administration - be it state or local government offices. Personally, I am in favor of uniformly defining the legal status of all 
public administration employees, as there is no rational justification that members of the civil service, local government employees and employees of state offices cannot be covered by similar ethical or professional standards, or that they are not subject to similar selection, recruitment evaluation or disciplinary responsibility. However, it is too early to say that the process of building the Polish civil service is completed, and thus too early to transfer these solutions from the area of government administration to local government or state.

Therefore, based on the above presented considerations on selected elements of the legal status of the civil service, but also bearing in mind the aforementioned discussion between representatives of the doctrine of labor and administrative law, as well as the current state of the act on local government employees and the act on employees of state offices that the Polish law of office still faces an identity crisis. Nevertheless, a recent - extremely important - Supreme Court ruling of 10 April $2014^{28}$ in which it was stated that the Head of the Civil Service as a central government administration body does not act in the field of labor law as an employer but performs its statutory powers of a public law, act of appointment is an act of applying the law by a public administration body (i.e. a unilateral, authoritative, declaration of will, thus shaping the individual legal situation of the person applying for appointment), and in the matter of determining the obligation of the Head of the Civil Service to issue this act an administrative route - allows the Polish administrative law attorneys to look with some hopes on the further course of the discussion on this identity of the Polish official law. 


\section{References}

1 Ustawa z dnia 21 listopada 2008 r. o służbie cywilnej; Dz. U. Nr 227, poz.1505 [Act of 21 November 2008 on civil service; Dz. U. No. 227, item 1505], www.prawo.sejm.gov.pl (accessed 20 May 2018).

2 Ustawa z dnia 5 lipca 1996 r. o służbie cywilnej; Dz. U. Nr 89, poz. 402 [Act of 5 July 1996 on civil service; Dz. U. No. 89, item 402], www.prawo.sejm.gov.pl (accessed 20 May 2018).

3 Ustawa z dnia 18 grudnia 1998 r. o służbie cywilnej; Dz. U. Nr 49, poz. 483 [Act of December 18, 1998 on Civil Service; Dz. U. No. 49, item 483], www.prawo.sejm.gov.pl (accessed 20 May 2018).

4 Ustawa z dnia 24 sierpnia 2006 r. o służbie cywilnej [Act of 24 August 2006 on civil service; Dz. U. no. 170, item 1218], www.prawo.sejm.gov.pl (accessed 20 May 2018).

5 Dz. U. z 2001 r., Nr 86, poz. 953 [Dz. U. of 2001, no. 86, item 953], www.prawo.sejm.gov.pl (accessed 20 May 2018). This Act covered the same category of officials in its subjective scope.

6 Dz. U. Nr 170, poz. 1217 [Dz. U. no. 170, item 1217], www.prawo.sejm.gov.pl (accessed 20 May 2018).

7 Teresa Górzyńska et al., System prawa administracyjnego, Tom 2 Konstytucyjne podstawy funkcjonowania administracji publicznej [System of administrative law, Volume 2 Constitutional grounds for the functioning of public administration], 452 (Warsaw, 2012).

8 Constitution of the Republic of Poland of April 2, 1997; Dz. U. of 1997 no. 78, item 483 (hereinafter referred to as the "Constitution of the Republic of Poland"), www.prawo.sejm.gov.pl. The text referring to Art. 153 is added as follows: ' 1 . In order to provide a professional, reliable, impartial and politically neutral performance of state tasks, the civil service corps functions in government administration offices. 2 . The Prime Minister is the head of the civil service corps.'

9 The most serious changes were introduced by the act of 30 December 2015 amending the act on civil service and some other acts; Dz. U. 2016, item 34 (ustawa z dnia 30 grudnia 2015 r. o zmianie ustawy o służbie cywilnej oraz niektórych innych ustaw; Dz. U. 2016, poz. 34), www.prawo.sejm.gov.pl (accessed 28 February 2019).

10 The joint constitutional complaint of the Ombudsman and a group of deputies awaiting consideration by the Constitutional Tribunal regarding the constitutionality of the aforementioned amendment of 2015, case no. K 6/16, www.trybunal.gov.pl/s/k-616/ (accessed 20 May 2018).

11 The first Polish law regulating the legal status of officials is the Act of 17 February 1922 on State Civil Service; Dz. U. of 1949 no. 11, item 72 (ustawa z 17 lutego 1922 r. o państwowej służbie cywilnej; Dz. U. z 1949 r. Nr 11, poz. 72).

12 Ustawa z dnia 26 czerwca 1974 r. - Kodeks pracy; Dz. U. z 1998 r. Nr 21, poz. 94 [Act of June 26, 1974 - Labor Code; Dz. U. of 1998 no. 21, item 94], www.prawo.sejm.gov.pl (accessed 20 May 2018).

13 Sygn. akt IV SA/Po 786/13 (Ref. act IV SA / Po 786/13), www.orzeczenia-nsa.pl (accessed 20 May 2018).

14 Ustawa z dnia 14 czerwca 1960 r. Kodeks postępowania administracyjnego; Dz. U. z 2000 r. Nr 98, poz. 1071 [The Act of June 14, 1960. The Code of Administrative Procedure; Dz. U. of 2000 No. 98, item 1071], www.prawo.sejm.gov.pl (accessed 20 May 2018).

15 W. Drobny, Glosa do postanowienia WSA $z$ dnia 8 maja $2012 \mathrm{r}$. [Gloss to the decision of the Provincial Administrative Court of 8 May 2012], VII SA / Wa 639/12, LEX / el 2012.

16 Sygn. akt III APa 4/14 [Ref. act III APa 4/14], www.orzeczenia.rzeszow.sa.gov.pl (accessed 20 May 2018).

17 Sygn. akt II PK 32/13 [Ref. act II PK 32/13], www.sn.pl (accessed 20 May 2018).

18 Ustawa z dnia 23 grudnia 1994 r. o Najwyższej Izbie Kontroli; Dz. U. 2012, poz. 82 [The Act of December 23, 1994 on the Supreme Audit Office; Dz. U. 2012, item 82], www.prawo.sejm.gov.pl (accessed 20 May 2018).

19 Ustawa z dnia 9 kwietnia 2010 r. o Służbie Więziennej, Dz.U. 2010, nr 79, poz. 523 [The Act of 9 April 2010 on the Prison Service, Dz.U. 2010, No. 79, item 523]; www.prawo.sejm.gov.pl (accessed 20 May 2018).

20 Zalecenie KM RM z 24 lutego 2000 r., R/2000/6 [RM RM Recommendation of 24 February 2000, R / 2000/6]. 
21 Wyrok TK z dnia 12 grudnia 2002 r., sygn. akt K 9/02 [Judgment of the Constitutional Tribunal of December 12, 2002, Ref. act K 9/02], www.trybunal.gov.pl (accessed 20 May 2018).

22 Sygn. akt K 51/02 [Ref. act K 51/02], www.trybunal.gov.pl (accessed 20 May 2018).

23 Jan Zimmermann, Prawo administracyjne [Administrative Law], 128 (Cracow, 2005).

24 Ustawa z dnia 14 czerwca 1991 r. o Krajowej Szkole Administracji Publicznej, Dz. U. Nr 63, poz. 266 [The Act of June 14, 1991 on the National School of Public Administration, Dz.U. U. no. 63, item 266], www. prawo.sejm.gov.pl (accessed 20 May 2018).

25 Postanowienie NSA z dnia 6 lutego 2013 r., sygn. akt I OSK 65/13 [Order of the Supreme Administrative Court of 6 February 2013, Ref. I I OSK 65/13 file]; www.orzeczenia.nsa.gov.pl (accessed 20 May 2018).

26 Sygn. akt VII SAB/Wa 45/12 [Ref. act VII SAB / Wa 45/12], www.orzeczenia.nsa.gov.pl (accessed 20 May 2018).

27 For example, the aforementioned judgment of the Provincial Administrative Court of 22 August 2012.

28 Sygn. akt II PK 259/13 [Ref. act II PK 259/13], www.sn.pl (accessed 20 May 2018). 